\title{
Article
}

Mycosphere

\section{Influence of endophytic fungi isolated from symptomless weeds on cherry plants}

\author{
Ilic $\mathbf{J}^{1}$, Cosic $\mathbf{J}^{1}$, Vrandecic $\mathrm{K}^{1}$, Dugalic $\mathrm{K}^{2}$, Pranjic $\mathrm{A}^{\mathbf{2}}$ and Martin $\mathbf{J}^{3}$ \\ ${ }^{1}$ Faculty of Agriculture in Osijek, K.P. Svacica 1d, 31000 Osijek, Croatia \\ ${ }^{2}$ Agricultural Institute Osijek, Juzno predgrade 17, 31000 Osijek, Croatia \\ ${ }^{3}$ Fundación MEDINA, Av. Conocimiento 3, 18016 Granada, Spain
}

Ilic J, Cosic J, Vrandecic K, Dugalic K, Pranjic A, Martin J. 2017 - Influence of endophytic fungi isolated from symptomless weeds on cherry plants. Mycosphere 8(1), 18-30, Doi 10.5943/mycosphere/8/1/3

\begin{abstract}
In standard pathogenicity tests of Fusarium strains isolated from symptomless weeds of agricultural fields it was determined that several isolates have significant positive influence on growth and development of cultivated plants and act as beneficial endophytes. The aim of this research was to investigate the influence of these isolates on several parameters of cherry plants grown in tissue culture. For this purpose two treatments with fungal inocula were used. The first treatment involved the addition of fungal inoculum into the tissue culture growing media. Cherry shoots were placed on the media and multiplied by tissue culture methods. The second treatment included root dipping of cherry explants into the fungal media. Plants were grown in the greenhouse for two months and after that growth parameters were recorded. Our results showed significant positive influence of the isolates on leaf width and length, stem length and plant fresh weight of cherry. There was almost no influence on number of leaves and root length of inoculated plants was lower as compared to the control. Identification of fungal secondary metabolites produced revealed several major compounds: beauverin, cyclosporines, enniatins, equisetin, fusaric acid, integracide A and trichosetin. Our conclusion is that endophytic Fusarium sp. isolated from weeds have a positive influence on growth and development of axenic cherry plants.
\end{abstract}

Key words - endophyte - Fusarium - integracide A - secondary metabolites - tissue culture

\section{Introduction}

Endophytes are microorganisms, mostly fungi and bacteria that live within plants intercellularly and/or intracellularly for at least a part of their life cycle without causing any visible manifestation of disease under normal circumstances (Hyde \& Soytong 2008, Delaye et al. 2013). During this association, none of the interacting partners is harmed, and the individual benefits depend on all organisms involved. Endophytic fungi that grow within their plant hosts without causing disease symptoms are relatively unexplored and unattended as compared with soil isolates and plant pathogens. Evidence of plant-associated microorganisms has been found in the fossilized tissues of stems and leaves which revealed that endophyte-plant associations may have evolved from the time when higher plants first appeared on Earth (Redecker et al. 2000). The existence of fungi inside asymptomatic plants has been known since the end of the 19th century (Guerin 1898), and the term "endophyte", was first proposed in 1866 by de Bary (1866). Since its first description 
by Freeman (1904) endophytes have been isolated from various organs of different plant species, from the tropics to the Arctic, and from the wild to agricultural ecosystems (Arnold 2007, Gundel et al. 2014, Keim et al. 2014). Biological diversity of endophytes is large and each plant species may be a host to a number of endophytes (Strobel 2003). According to Petrini (1986) endophytes have been found in all parts of all plants, including xylem and phloem. Most endophytic fungi belong to the Ascomycetes and their asexual morphs. They are not generally considered as saprobes (although they may become saprobes at plant death (Promputtha et al. 2010), since they are associated with living tissues, and may in some way contribute to the well-being of the plant. Endophytes are thought to play multiple physiological and ecological roles in the mutualistic association with their host plants (Hardoim et al. 2015). The plant might provide nutrients to the microbe and the microbe may produce metabolites that protect the host plant from attack by animals, insects or other microbes, improve its tolerance to environmental stress (drought tolerance, metal tolerance) and positively influence plant growth and development (Rolli et al. 2015). It is conceivable that plant communities would not be able to survive a number of environmental stresses without symbiotic associations with endophytic fungi. Many endophytes are known to be an important source of secondary metabolites and plant hormones (Hardoim et al. 2015, LudwigMüller 2015, Muria-Gonzalez et al. 2015) and have the potential to synthesize various bioactive metabolites that may be used as therapeutic agents against numerous diseases (Aharwal et al. 2016). Previous investigations discovered endophytes that produce host plant secondary metabolites with therapeutic value or potential (Stierle et al. 1993), such as paclitaxel (also known as Taxol). But this has been disputed (Heinig et al. 2013). Although many authors have investigated endophytic fungi, the genetic and bio-chemical processes responsible for their activity remain unknown. According to Andrews et al. (2010), current agricultural practice is facing problems related to the increased use of chemical protection and fertilizers and is searching for alternative strategies to improve plant growth and resistance in order to have better yield. In that sense, extensive use of microorganisms in agricultural systems and positive plant microbial interactions could lead to reduction in use of artificial enhancers.

The aim of this study was to determine the influence of endophytic Fusarium living inside symptomless weeds growing in or near agricultural fields, on growth and development of cultivated plants.

\section{Materials and methods}

Previously isolated Fusarium species from symptomless weed and plant debris (Postic et al. 2012) were used for pathogenicity tests on wheat and maize (Ilic et al. 2012). Some isolates were pathogenic and some showed positive influence on growth and development of wheat and maize. Five of these Fusarium species (Table 1). showing positive influence were selected and used to investigate their influence on growth of cherry explants grown in tissue culture.

Pathogenicity of these isolates has been previously investigated in Ilic et al. (2012) and the above mentioned Fusarium isolates showed positive influence to wheat and maize development.

\section{Inoculation of tissue culture media with endophytes (Treatment 1)}

The five-selected species of Fusarium spp. were grown on PDA (4 petri-dishes for each isolate) for 14 days in growing chambers, at $22^{\circ} \mathrm{C}$ and 12 hour day/12 hour night regime. After 14 days mycelia were removed from the medium surface by scraping with sterile metal scalpel. Since most of the isolates did not sporulate or produced only a small number of spores after incubation, the whole mycelia was blended with $160 \mathrm{ml}$ of distilled water and refrigerated at $4^{\circ} \mathrm{C} .20 \mathrm{ml}$ of endophytes suspension was injected into a warm (approx. $40 \mathrm{C}^{\mathrm{o}}$ ), still liquid introduction media through injection with a filter (Schenk \& Hildebrandt Basal medium, Schenk \& Hildebrandt 1972), Murashige Skoog medium (Murashige \& Skoog 1962), BAP - 6-benzylaminopurine, NAA - 1naphthaleneacetic acid, GA3 - gibberellic acid, sucrose and agar. 
Table 1 Fusarium isolates used in this study and their weed hosts

\begin{tabular}{ll}
\hline Fusarium species & Weed \\
\hline $\begin{array}{l}\text { Fusarium oxysporum Schlechtendahl emend. Snyder \& Hansen, isolate } \\
\text { no. } 61\end{array}$ & Abutilon theoprasti Med. \\
Fusarium solani (Martius) Appel \& Wollenweber emend. Snyder \& & Sonchus arvensis L. \\
Hansen, isolate no. 149 & \\
Fusarium solani isolate no. 112 & Chenopodium album L. \\
Fusarium subglutinans (Wollenweber \& Reinking) Nelson, Tousson \& & Chenopodium album L. \\
Marasas, isolate no. 111 & \\
Fusarium verticillioides (Sacc.) Nirenberg (Nirenberg and O'Donnell), & Chenopodium album L. \\
isolate no. 102 & \\
\hline
\end{tabular}

\section{Preparation of tissue culture plants}

As described by Pereira et al. (1999), apical meristems of cherry were obtained from vegetative buds of intact, two-year-old mother plants grown in the greenhouse. Surface of culture introduction buds were sterilized with Na-hypochlorite and $75 \%$ ethanol. Meristems were aseptically excised and explants were placed into the introduction medium containing endophytic fungi. Light was provided with cool light fluorescent bulbs located $20 \mathrm{~cm}$ above the containers. Light intensity at the top of containers was 40 to $60 \mu \mathrm{mol} \cdot \mathrm{m}^{-2} \cdot \mathrm{s}^{-1}$. Micro-propagated shoots were maintained in glass tubes, one shoot per tube, at $25{ }^{\circ} \mathrm{C}, 16$ hour photoperiod and transferred biweekly. When the plantlets were $2-4 \mathrm{~cm}$ tall, callus was removed and leaf surface reduced. Each plant was divided into at least two plants, depending on the development of the plantlet, and transferred to flasks containing multiplication media (macro elements, micro elements and vitamins - Driver Kuniyuki medium (DKW) (Driver \& Kuniyuki, 1984), BAP, IBA - Indole-3-butyric acid, agar and myo-inositol).

This procedure was repeated 6 times, and finally, plantlets were transferred to rooting media (macroelements, microelements and vitamins - MS medium, IBA, Sequestren $138 \mathrm{Fe} 100 \mathrm{SG}$, and agar). 50 shoots were placed into jars for root development and then cool stored for 4 weeks, to improve transplantation according to results of Varshney et al. (2000).

Explants in each experiment were obtained from the same subculture cycle. After 28 days in root development medium, rooted shoots were washed thoroughly to remove residual medium and re-inoculated with fungal suspension.

\section{Re-inoculation of cherry plants with fungal suspension (Treatment 2)}

In the transplanting stage, 40 cherry explants were selected based on their uniformity in size and growth vigor. The selected seedlings were artificially infected with fungal suspension. The five selected Fusarium isolates were prepared with the same procedure mentioned previously. Three $500 \mathrm{ml}$ beakers, each containing mycelial and conidia suspension, were prepared for each isolate. Dip inoculations were performed according to the modified method from Gera Hol et al. (2007) by simultaneously dipping the whole plants into a $500 \mathrm{ml}$ beaker for one hour. Whole plants were dipped instead of only roots due to small plant size. Rooted plantlets were potted into plastic boxes with space for 40 plants and containing substrate with macro elements, microelements and perlit. Plants in boxes were placed under a plastic tent on a bench in a fan and pad greenhouse, where humidity was maintained at $99 \%$ in the first week using a humidifier. Temperature of the substrate was between 18 and $21^{\circ} \mathrm{C}$ and temperature in the tent was approximately $25^{\circ} \mathrm{C}$. In vivo conditions were gradually introduced by reducing moisture and exposing plants to more light. Once a week plants were treated with fungicide Previcur Energy to prevent Pythium infection and with insecticide Dursban against mushroom fly Amanita muscaria (L.) Lam. Plants were fertilized once a week by root immersion with fertilizer Polyphid. After 4 weeks of acclimatization, tents were removed and plants adjusted completely. Plants remained in controlled greenhouse for an additional 30 days. Plant fresh weight, stem length (distance from pseudostem base to the point where the youngest leaf emerges from the pseudostem), number of functional leaves, width at the 
widest point and length of the largest leaf, and root length were recorded. Dry weight was not recorded because the same plants were used for further research.

\section{Secondary metabolites identification and characterization}

Fusarium were grown on PDA agar for two weeks under the same regime mentioned above. Four Petri dishes were prepared for each of the five Fusarium species. After two weeks, $20 \mathrm{ml}$ of methanol was added to each Petri dish, sealed with parafilm and left to rest for 24 hours. After 24 hours, methanol extracts were collected and methanol was evaporated. Extracts were analyzed at Fundación MEDINA center in Granada, Spain, where extracts were completely dried under nitrogen current and reconstituted in $100 \mu \mathrm{l}$ of DMSO with a further addition of $400 \mu \mathrm{l}$ of water. Samples were sonicated for 15 minutes and filtered. Two micro liters of the extracts were analyzed by LC-MS. Analysis was performed on an Agilent (Santa Clara, California, USA) 1100 single Quadrupole LC-MS, by using a Zorbax SB-C8 column $(2.1 \times 30 \mathrm{~mm})$, maintained at $40^{\circ} \mathrm{C}$ and with a flow rate of $300 \mu \mathrm{l} / \mathrm{min}$. Solvent A was $10 \%$ acetronitrile and $90 \%$ water with $1.3 \mathrm{mM}$ trifluoroacetic acid (TFA) and ammonium formate, while solvent B was $90 \%$ acetronitrile and $10 \%$ water with $1.3 \mathrm{mM}$ TFA and ammonium formate. The gradient started at $10 \% \mathrm{~B}$ and went to $100 \%$ $\mathrm{B}$ in 6 minutes, kept at $100 \% \mathrm{~B}$ for 2 minutes and returned to $10 \% \mathrm{~B}$ for 2 minutes to initialize the system. Full diode array UV scans going from 200 to $900 \mathrm{~nm}$ were collected in $4 \mathrm{~nm}$ steps at 0.25 $\mathrm{sec} / \mathrm{scan}$. Ionization of the eluting solvent was achieved by using the standard Agilent 1100 ESI source adjusted to a drying gas flow of $11 \mathrm{1} / \mathrm{min}$ at $325^{\circ} \mathrm{C}$ and a nebulizer pressure of $40 \mathrm{psig}$. The capillary voltage was set to $3500 \mathrm{~V}$. Full scans of mass spectra were collected from $150 \mathrm{~m} / \mathrm{z}$ to $1500 \mathrm{~m} / \mathrm{z}$, with one scan every 0.77 seconds, in both positive and negative modes. An in house developed application was used for database matching (Zink et al. 2002, 2005) where the DAD, retention time, POS and NEG mass spectra of the extracts were compared to the UV-LC-MS spectral data of known metabolites stored in a proprietary database.

\section{Data analysis}

Statistical analysis of data was performed with the help of the SAS software application. Mann Whitney U test was used for inter-group comparisons.

\section{Results}

Plants inoculated with $F$. solani 112 died during the tissue culture treatment. The remaining treatments showed significant influence on growth parameters. This can be seen in Figure 1. where comparisons between treatments of each species and controls are shown.

After measurement and statistical analysis we concluded that almost all parameters in both treatments showed statistically significant difference compared to control (Table 1. and Table 2.). Positive difference was recorded for leaf length and width, stem length and plant fresh weight, while negative difference was recorded for root length. In other words, control plants had longer roots compared to treated plants. When it comes to number of leaves, both treatments mostly did not have significant influence, except for treatment 2 on isolate 149 (Fig. 2). Comparison of both treatments can be seen in Fig. 2.

Both treatments had the same positive influence on leaf width, stem length and plant fresh weight of isolate 102. Treatment 1 had higher influence on leaf length (Table 4.).

For isolate 149, both treatments had the same influence on stem lenght. Treatment 1 had higher influence on leaf lenght, width and plant fresh weight, while treatment 2 had higher influence on number of leaves (Table 5).

The highest number of very significant differences $(p<0,005)$ compared to control and all treatments had isolate 149 . 


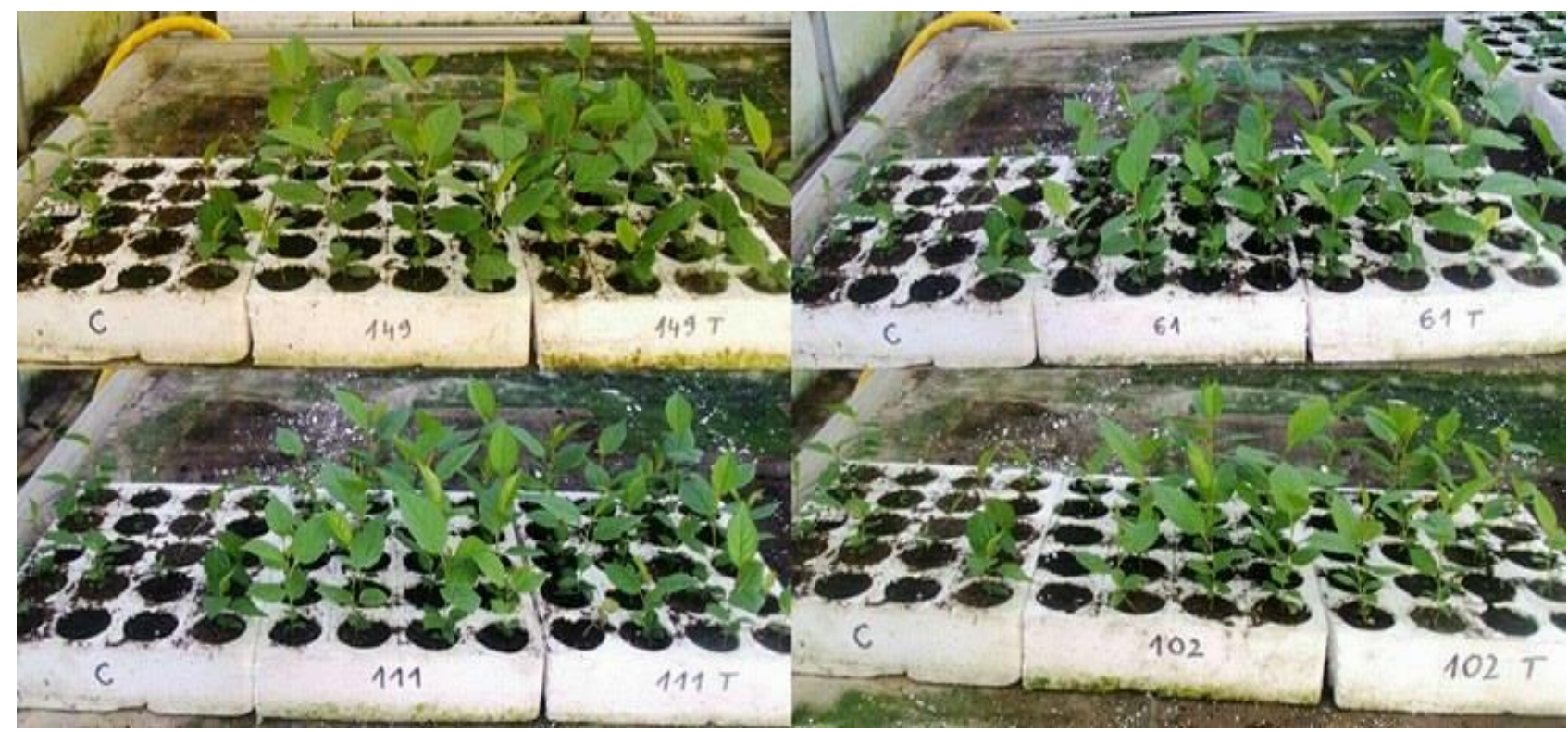

Fig. 1 - Control cherry plantlets $(\mathbf{C})$ compared to plantlets grown on tissue culture media inoculated with fungi (Treatment 1) and plantlets grown on same media and also plant dipped into fungal suspension (Treatment 2); top left) $F$. solani 149, top right) $F$. oxysporum, bottom left) $F$. subglutinans, bottom right) $F$. verticillioides.

Table 1 Statistical analysis of the effect of Fusarium inoculation - treatment 1 on anatomical parameters of cherry

\begin{tabular}{lllllll}
\hline Isolates & $\begin{array}{l}\text { Number of } \\
\text { leaves }\end{array}$ & $\begin{array}{l}\text { Leaf lenght } \\
(\mathbf{c m})\end{array}$ & $\begin{array}{l}\text { Leaf width } \\
(\mathbf{c m})\end{array}$ & $\begin{array}{l}\text { Stem lenght } \\
(\mathbf{c m})\end{array}$ & $\begin{array}{l}\text { Root lenght } \\
(\mathbf{c m})\end{array}$ & $\begin{array}{l}\text { Plant fresh } \\
\text { weight }(\mathbf{g})\end{array}$ \\
\hline Control & $9.80 \mathrm{ab}$ & $3.64 \mathrm{~d}$ & $2.33 \mathrm{~d}$ & $3.68 \mathrm{~d}$ & $4.90 \mathrm{a}$ & $0.45 \mathrm{~d}$ \\
111 & $10.30 \mathrm{a}$ & $5.41 \mathrm{~b}$ & $3.41 \mathrm{~b}$ & $7.37 \mathrm{~b}$ & $3.50 \mathrm{~b}$ & $0.79 \mathrm{~b}$ \\
149 & $10.37 \mathrm{a}$ & $6.07 \mathrm{a}$ & $3.87 \mathrm{a}$ & $9.77 \mathrm{a}$ & $3.53 \mathrm{~b}$ & $1.21 \mathrm{a}$ \\
61 & $9.33 \mathrm{~b}$ & $4.97 \mathrm{c}$ & $2.96 \mathrm{c}$ & $7.41 \mathrm{~b}$ & $2.45 \mathrm{c}$ & $0.66 \mathrm{c}$ \\
102 & $9.66 \mathrm{~b}$ & $5.17 \mathrm{bc}$ & $3.15 \mathrm{bc}$ & $6.27 \mathrm{c}$ & $3.42 \mathrm{~b}$ & $0.73 \mathrm{bc}$
\end{tabular}

$\mathrm{a}, \mathrm{b}, \overline{c,}$ - different letters mark statistically significant difference according to Duncan's Multiple Range Test at the level $\mathrm{P} \leq 0.95$

Table 2 Statistical analysis of the effect of Fusarium inoculation - treatment 2 on anatomical parameters of cherry

\begin{tabular}{lllllll}
\hline Isolates & $\begin{array}{l}\text { Number of } \\
\text { leaves }\end{array}$ & $\begin{array}{l}\text { Leaf lenght } \\
(\mathbf{c m})\end{array}$ & $\begin{array}{l}\text { Leaf width } \\
(\mathbf{c m})\end{array}$ & $\begin{array}{l}\text { Stem lenght } \\
(\mathbf{c m})\end{array}$ & $\begin{array}{l}\text { Root lenght } \\
(\mathbf{c m})\end{array}$ & $\begin{array}{l}\text { Plant fresh } \\
\text { weight }(\mathbf{g})\end{array}$ \\
\hline Control & $9.80 \mathrm{bc}$ & $3.64 \mathrm{c}$ & $2.33 \mathrm{c}$ & $3.68 \mathrm{~d}$ & $4.90 \mathrm{a}$ & $0.46 \mathrm{c}$ \\
111 & $9.20 \mathrm{c}$ & $4.45 \mathrm{~b}$ & $2.76 \mathrm{~b}$ & $6.22 \mathrm{c}$ & $3.58 \mathrm{~b}$ & $0.59 \mathrm{~b}$ \\
149 & $10.65 \mathrm{a}$ & $5.53 \mathrm{a}$ & $3.36 \mathrm{a}$ & $8.71 \mathrm{a}$ & $3.10 \mathrm{c}$ & $1.00 \mathrm{a}$ \\
61 & $10.41 \mathrm{ab}$ & $5.32 \mathrm{a}$ & $3.24 \mathrm{a}$ & $7.41 \mathrm{~b}$ & $3.05 \mathrm{c}$ & $0.91 \mathrm{a}$ \\
102 & $10.21 \mathrm{ab}$ & $4.66 \mathrm{~b}$ & $2.95 \mathrm{~b}$ & $6.05 \mathrm{c}$ & $2.65 \mathrm{~d}$ & $0.69 \mathrm{~b}$
\end{tabular}

a,b,c, - different letters mark statistically significant difference according to Duncan's Multiple Range Test at the level $\mathrm{P} \leq 0.95$ 


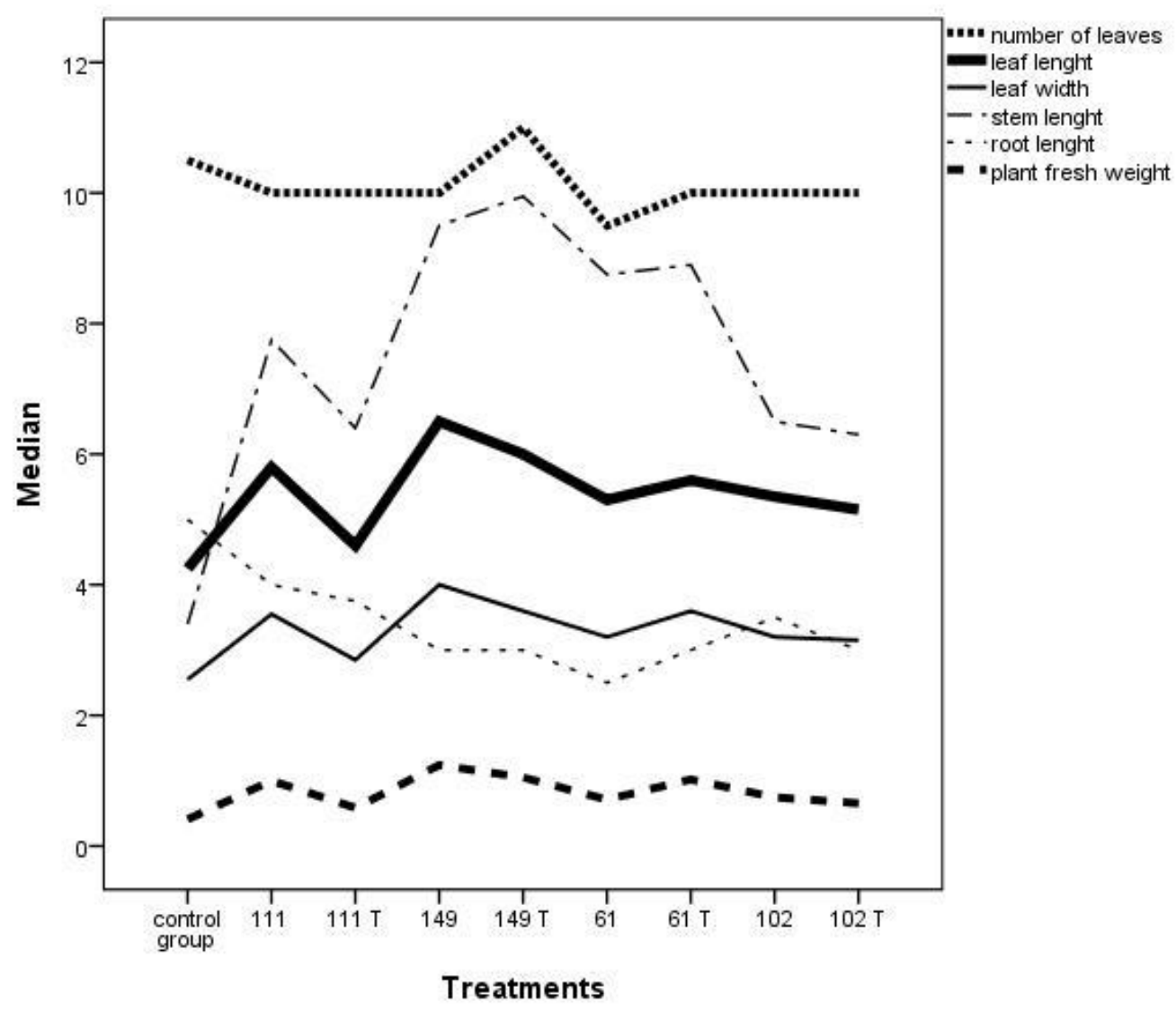

Fig. 2 - Comparison of influence of both treatments on growth parameters of cherry. Number alone indicates single treatment, while number $+\mathrm{T}$ indicates double treatment.

Table 3 Statistical analysis of the differences between the control, treatment 1 and treatment 2 for the isolate 61

\begin{tabular}{lllllll}
\hline Isolates & $\begin{array}{l}\text { Number of } \\
\text { leaves }\end{array}$ & $\begin{array}{l}\text { Leaf lenght } \\
(\mathbf{c m})\end{array}$ & $\begin{array}{l}\text { Leaf width } \\
(\mathbf{c m})\end{array}$ & $\begin{array}{l}\text { Stem lenght } \\
(\mathbf{c m})\end{array}$ & $\begin{array}{l}\text { Root lenght } \\
(\mathbf{c m})\end{array}$ & $\begin{array}{l}\text { Plant fresh } \\
\text { weight }(\mathbf{g})\end{array}$ \\
\hline Control & $9.8 \mathrm{ab}$ & $3.64 \mathrm{~b}$ & $2.33 \mathrm{~b}$ & $3.68 \mathrm{~b}$ & $4.90 \mathrm{a}$ & $0.45 \mathrm{c}$ \\
61 & $9.33 \mathrm{~b}$ & $4.97 \mathrm{a}$ & $2.96 \mathrm{a}$ & $7.41 \mathrm{a}$ & $3.05 \mathrm{~b}$ & $0.66 \mathrm{~b}$ \\
$61 \mathrm{t}$ & $10.41 \mathrm{a}$ & $5.32 \mathrm{a}$ & $3.24 \mathrm{a}$ & $7.41 \mathrm{a}$ & $2.45 \mathrm{c}$ & $0.91 \mathrm{a}$ \\
\hline $\mathrm{a}, \mathrm{b}, \mathrm{c}-$ different letters mark statistically significant & difference according to Duncan's Multiple Range Test at the level $\mathrm{P} \leq$ \\
0.95 &
\end{tabular}

Table 4 Statistical analysis of the differences between the control, treatment 1 and treatment 2 for the isolate 102

\begin{tabular}{lllllll}
\hline Isolates & $\begin{array}{l}\text { Number of } \\
\text { leaves }\end{array}$ & $\begin{array}{l}\text { Leaf lenght } \\
(\mathbf{c m})\end{array}$ & $\begin{array}{l}\text { Leaf width } \\
(\mathbf{c m})\end{array}$ & $\begin{array}{l}\text { Stem lenght } \\
(\mathbf{c m})\end{array}$ & $\begin{array}{l}\text { Root lenght } \\
(\mathbf{c m})\end{array}$ & $\begin{array}{l}\text { Plant fresh } \\
\text { weight }(\mathbf{g})\end{array}$ \\
\hline Control & $9.80 \mathrm{a}$ & $3.64 \mathrm{c}$ & $2.33 \mathrm{~b}$ & $3.68 \mathrm{~b}$ & $4.90 \mathrm{a}$ & $0.45 \mathrm{~b}$ \\
102 & $9.66 \mathrm{a}$ & $5.17 \mathrm{a}$ & $3.15 \mathrm{a}$ & $6.27 \mathrm{a}$ & $3.42 \mathrm{~b}$ & $0.73 \mathrm{a}$ \\
$102 \mathrm{t}$ & $10.21 \mathrm{a}$ & $4.66 \mathrm{~b}$ & $2.95 \mathrm{a}$ & $6.05 \mathrm{a}$ & $2.65 \mathrm{c}$ & $0.69 \mathrm{a}$ \\
\hline $\mathrm{a}, \mathrm{b}, \mathrm{c}-$ different letters mark statistically significant difference according to Duncan's Multiple Range Test at the level $\mathrm{P} \leq$
\end{tabular}
0.95

Treatment 1 had more positive influence on leaf length and width, stem lenght and plant fresh weight of isolate 111 (Table 6.). 
Table 5 Statistical analysis of the differences between the control, treatment 1 and treatment 2 for the isolate 149

\begin{tabular}{lllllll}
\hline Isolates & $\begin{array}{l}\text { Number of } \\
\text { leaves }\end{array}$ & $\begin{array}{l}\text { Leaf lenght } \\
(\mathbf{c m})\end{array}$ & $\begin{array}{l}\text { Leaf width } \\
(\mathbf{c m})\end{array}$ & $\begin{array}{l}\text { Stem lenght } \\
(\mathbf{c m})\end{array}$ & $\begin{array}{l}\text { Root lenght } \\
(\mathbf{c m})\end{array}$ & $\begin{array}{l}\text { Plant fresh } \\
\text { weight }(\mathbf{g})\end{array}$ \\
\hline Control & $9.80 \mathrm{~b}$ & $3.64 \mathrm{c}$ & $2.33 \mathrm{c}$ & $3.68 \mathrm{~b}$ & $4.90 \mathrm{a}$ & $0.45 \mathrm{c}$ \\
149 & $10.37 \mathrm{ab}$ & $6.07 \mathrm{a}$ & $3.87 \mathrm{a}$ & $9.77 \mathrm{a}$ & $3.53 \mathrm{~b}$ & $1.21 \mathrm{a}$ \\
$149 \mathrm{t}$ & $10.65 \mathrm{a}$ & $5.53 \mathrm{~b}$ & $3.36 \mathrm{~b}$ & $8.71 \mathrm{a}$ & $3.10 \mathrm{~b}$ & $1.00 \mathrm{~b}$
\end{tabular}

a,b,c - different letters mark statistically significant difference according to Duncan's Multiple Range Test at the level $\mathrm{P} \leq$ 0.95

Table 6 Statistical analysis of the differences between the control, treatment 1 and treatment 2 for the isolate 111

\begin{tabular}{lllllll}
\hline Isolates & $\begin{array}{l}\text { Number of } \\
\text { leaves }\end{array}$ & $\begin{array}{l}\text { Leaf lenght } \\
(\mathbf{c m})\end{array}$ & $\begin{array}{l}\text { Leaf width } \\
(\mathbf{c m})\end{array}$ & $\begin{array}{l}\text { Stem lenght } \\
(\mathbf{c m})\end{array}$ & $\begin{array}{l}\text { Root lenght } \\
(\mathbf{c m})\end{array}$ & $\begin{array}{l}\text { Plant fresh } \\
\text { weight }(\mathbf{g})\end{array}$ \\
\hline Control & $9.80 \mathrm{ab}$ & $3.64 \mathrm{c}$ & $2.33 \mathrm{c}$ & $3.68 \mathrm{c}$ & $4.90 \mathrm{a}$ & $0.45 \mathrm{c}$ \\
111 & $10.30 \mathrm{a}$ & $5.41 \mathrm{a}$ & $3.41 \mathrm{a}$ & $7.37 \mathrm{a}$ & $3.50 \mathrm{~b}$ & $0.79 \mathrm{a}$ \\
$111 \mathrm{t}$ & $9.20 \mathrm{~b}$ & $4.45 \mathrm{~b}$ & $2.76 \mathrm{~b}$ & $6.22 \mathrm{~b}$ & $3.58 \mathrm{~b}$ & $0.59 \mathrm{~b}$
\end{tabular}

a,b,c - different letters mark statistically significant difference according to Duncan's Multiple Range Test at the level $\mathrm{P} \leq$ 0.95

Table 7 Compounds identified in the methanol fungal crude extract by LC-MS

\begin{tabular}{|c|c|c|c|c|c|}
\hline Fusarium spp. & $\begin{array}{l}\text { Retention } \\
\text { time } \\
(\min ) \\
\end{array}$ & $\begin{array}{l}\text { Compound } \\
\text { name }\end{array}$ & $\begin{array}{l}\text { Molecular } \\
\text { weight }\end{array}$ & $\begin{array}{l}\text { Molecular } \\
\text { formula }\end{array}$ & $\begin{array}{l}\text { Area } \\
\% \\
\end{array}$ \\
\hline \multirow[t]{3}{*}{ Fusarium oxyporum 61} & 1.15 & fusaric acid & 179,2 & $\mathrm{C}_{10} \mathrm{H}_{13} \mathrm{NO}_{2}$ & 25.1 \\
\hline & 5.78 & trichosetin & 359,5 & $\mathrm{C}_{21} \mathrm{H}_{29} \mathrm{NO}_{4}$ & 3.5 \\
\hline & 6.98 & beauverin & 784,0 & $\mathrm{C}_{45} \mathrm{H}_{57} \mathrm{~N}_{3} \mathrm{O}_{4}$ & 3.5 \\
\hline Fusarium solani I 149 & 4.90 & $\begin{array}{l}\text { integracide A } \\
\text { To Be }\end{array}$ & 594,8 & $\mathrm{C}_{32} \mathrm{H}_{50} \mathrm{O}_{8} \mathrm{~S}$ & 35.8 \\
\hline \multirow[t]{3}{*}{ Fusarim solani II 112} & 3.87 & Determined & 342,4 & $\mathrm{C}_{18} \mathrm{H}_{30} \mathrm{O}_{6}$ & 8.5 \\
\hline & 5.52 & cyclosporine $\mathrm{C}$ & 1218,6 & $\mathrm{C}_{62} \mathrm{H}_{111} \mathrm{~N}_{11} \mathrm{O}_{13}$ & 0.6 \\
\hline & 6.83 & cyclosporine A & 1202,6 & $\mathrm{C}_{62} \mathrm{H}_{111} \mathrm{~N}_{11} \mathrm{O}_{12}$ & 6.5 \\
\hline \multicolumn{6}{|l|}{ Fusarium subglutinans } \\
\hline \multirow[t]{3}{*}{111} & 6.60 & $\begin{array}{l}\text { enniatin B } \\
\text { enniatin B1 or }\end{array}$ & 639,8 & $\mathrm{C}_{33} \mathrm{H}_{57} \mathrm{~N}_{3} \mathrm{O}_{9}$ & 14.5 \\
\hline & 6.80 & $\mathrm{D}$ & 653,8 & $\mathrm{C}_{34} \mathrm{H}_{59} \mathrm{~N}_{3} \mathrm{O}_{9}$ & 3.7 \\
\hline & 7.02 & enniatin A & 681,9 & $\mathrm{C}_{36} \mathrm{H}_{63} \mathrm{~N}_{3} \mathrm{O}_{9}$ & 1.3 \\
\hline \multicolumn{6}{|l|}{ Fusarium verticilloides } \\
\hline \multirow[t]{4}{*}{102} & 0.99 & fusaric acid & 179,2 & $\mathrm{C}_{10} \mathrm{H}_{13} \mathrm{NO}_{2}$ & 7.7 \\
\hline & 5.77 & trichosetin & 359,5 & $\mathrm{C}_{21} \mathrm{H}_{29} \mathrm{NO}_{4}$ & 15.3 \\
\hline & 6.11 & equisetin & 373,5 & $\mathrm{C}_{22} \mathrm{H}_{31} \mathrm{NO}_{4}$ & 13.0 \\
\hline & 9.97 & beauverin & 784,0 & $\mathrm{C}_{45} \mathrm{H}_{57} \mathrm{~N}_{3} \mathrm{O}_{4}$ & 4.0 \\
\hline
\end{tabular}

\section{Secondary metabolites}

After chemical analysis of fungal extracts several metabolites were identified as main components (Table 7 and Fig. 3 and 4). Fusaric acid, trichosetin and beauverin were the main components of both $F$. oxysporum and $F$. verticillioides isolates. As shown in Table 3, other components detected were characteristic for each of the Fusarium isolates 


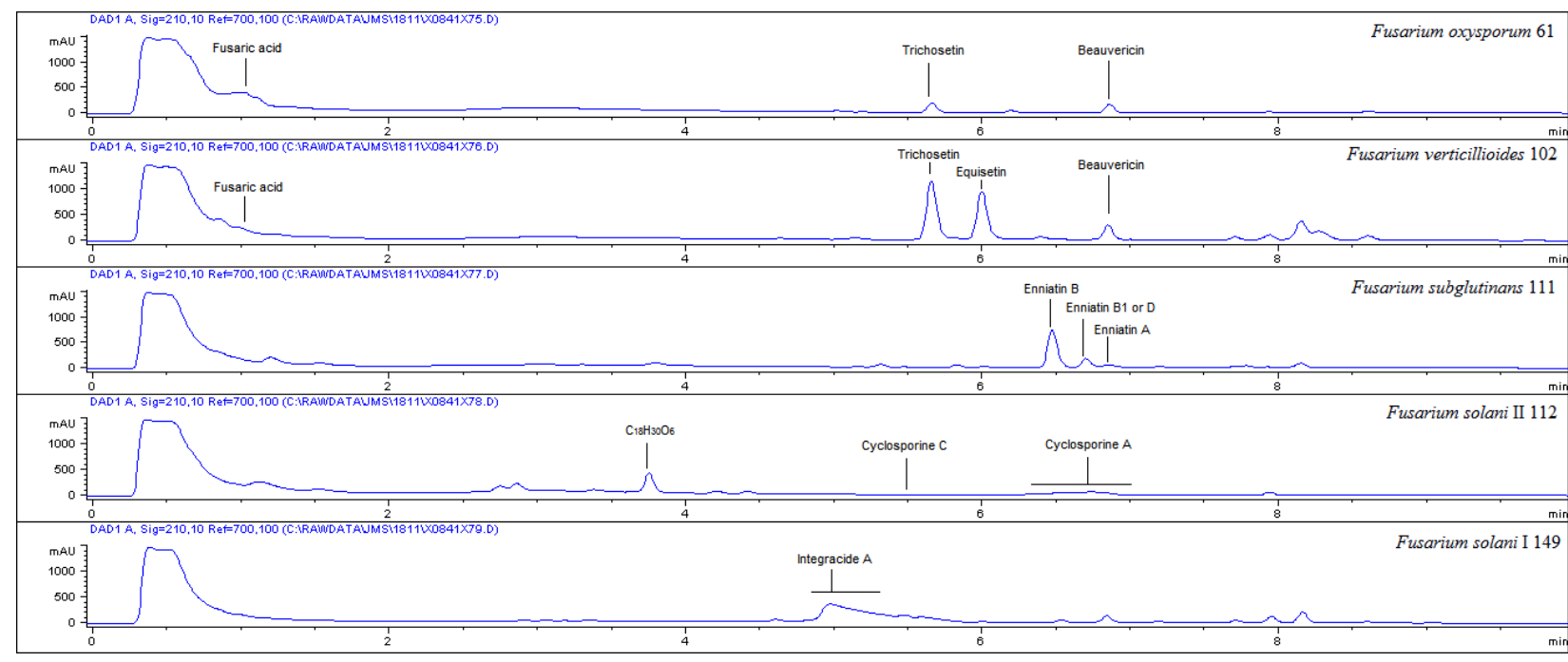

Fig. 3 - Profile of the most relevant metabolites from the fungi involved in the study

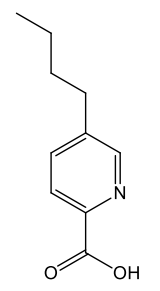

Fusaric acid

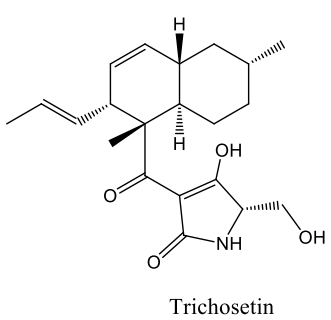

Trichosetin

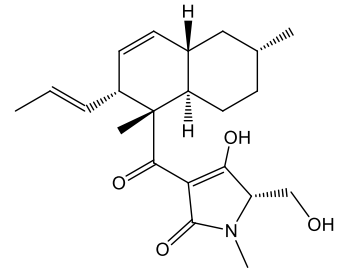

Equisetin

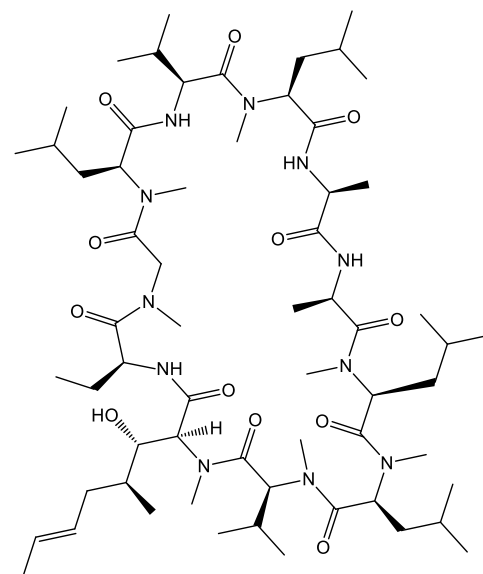

Cyclosporin A

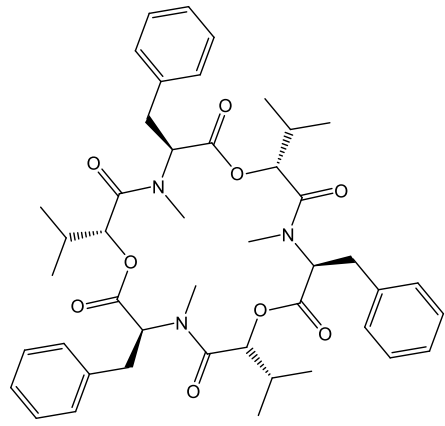

Beauvericin
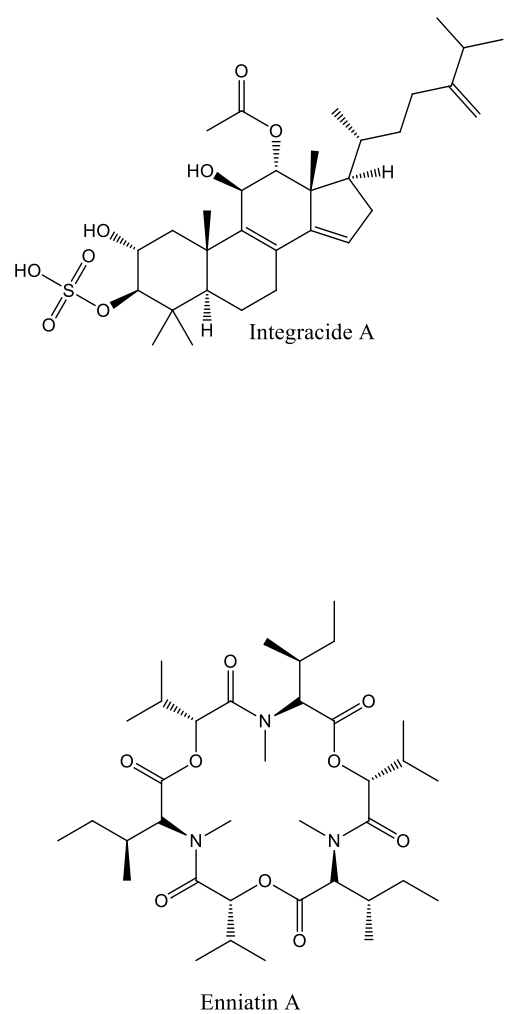

Enniatin A

Fig. 4 - Chemical structures of detected secondary metabolites 


\section{Discussion}

The objective of this study was to determine the influence of five different Fusarium isolates on growth parameters of cherry grown from tissue culture. After the measurement and statistical analysis it was determined that the majority of parameters were significantly higher after the treatment with endophytes. The number of leaves was the only parameter that did not show significant difference compared with the control in all but one case. Control plants also had longer roots as compared to treated plants. During the process of measurement we noticed that plant development was not correlated with the number of leaves and that smaller plants tend to have more leaves. We also noticed that root length did not correlate with plant length and weight, and small plants tended to have longer roots and vice versa.

Treatment 1 (media inoculation) had more significant influence on several growth parameters than treatment 2 (media + plant inoculation). This was a surprising fact since after the second treatment plants were infected twice with the same taxa and therefore would suggest a higher influence on plant growth.

The results shown previously indicate that all but one of the Fusarium isolates used for artificial infection of cherry plants had positive influence on the majority of plant growth parameters. Clonal plants grown under the same conditions should definitely look alike with only small differences in their growth, and contrary to that, in our research we have observed significant differences between treatments and control and also among treatments. Difference in plant size was not noticeable during in vitro conditions, but it was appreciable after greenhouse growing.

As mentioned previously, Fusarium endophytes used in this research were isolated from symptomless weeds. Little research has been done so far to determine endophytic fungi living inside weeds. In regard to agricultural production, weeds growing inside or near agricultural fields are especially interesting because they are more resistant to diseases than cultivated plants and as such might be an important bridge for pathogen survival during unfavorable conditions. Weeds might provide fitness enhancement to fungal species living inside them. In our previous research we have proven that endophytic fungi isolated from symptomless weed can act both as pathogens and beneficiaries towards cultivated plants (Ilic et al., 2012). Since weeds can harbor both pathogenic and non-pathogenic fungal species it is possible that they developed mechanisms where beneficial fungi helped them to prevent disease development. Machungo et al. (2009) studied the effect of endophytic $F$. oxysporum on growth of tissue cultured banana plants. They noticed an improvement in all parameters for plants inoculated with endophytes compared to controls. Varma et al. 1999. studied the influence of endophytic fungi Piriformospora indica on maize (Zea mays L.), tobacco (Nicotiana tabaccum L.), parsley (Petroselinum crispum L. 'Hamburger Schnitt'), Artemisia annua L., Bacopa monnieri L. and poplar (Populus tremula L.) and proved its positive influence to size and weight in plant shoots and roots.

Heslin and Douglas (1986) investigated influence of ectomycorrhizal fungi Paxillus involutus, Hebeloma crustuliniforme and Thelephora terrestris in plant development. Fungi were inoculated in a peat/vermiculite mixture during plant acclimatization from conditions in vitro to conditions in the glasshouse. According to their results, survival of inoculated plants was lower compared to uninoculated controls. Lowest survival (60\%) was noted under the influence of $T$. terrestris. On the other hand, T. terrestris gave the highest frequency of root infections, a significant increase in shoot height and a doubling of shoot dry weight. The content of $\mathrm{N}, \mathrm{P}$ and $\mathrm{K}$ in infected plants was also higher compared to control.

Obledo et al. (2003) isolated non-pathogenic strain of Fusarium oxysporum from fieldgrowing plants of Agave victoria-reginae Moore. This strain was used for artificial infection of micro propagated plants of A. victoria-reginae in the greenhouse. Inoculated plants had a $225 \%$ increase in root length, 50\% increase in the number of root branches and 50\% increase in the number of stomata. Total chlorophyll and sugar content were also increased by $14 \%$ and $172 \%$ respectively. Their results indicate that plants inoculated with the fungus have a higher photosynthetic efficiency compared to uninoculated plants, which is considered a beneficial symbiosis. 
Analysis of secondary metabolites of endophytic Fusarium species used in this experiment revealed the following secondary metabolites: fusaric acid, trichosetin, beauverin, integracide A, cyclosporine $\mathrm{C}$, cyclosporine $\mathrm{A}$, enniatin $\mathrm{B}$, enniatin $\mathrm{B} 1$ or $\mathrm{D}$, enniatin $\mathrm{A}$, including one unknown compound whose chemistry would have to be determined. $F$. oxysporum 61 had one major peak with retention time $1.15 \mathrm{~min}$ and area percentage 25.1, which was determined as fusaric acid. Isolate also included trichosetin and beauverin. The highest peak of $F$. solani 149 was determined to be integracide A with retention time $4.9 \mathrm{~min}$ and area percentage $35.8 \%$. The highest peak of $F$. solani 112 turned out to be an unknown compound. Besides that it also included cyclosporine A and C. F. subglutinans 111 had enniatin B as the highest peak with retention time 6.6 and area percentage $14.5 \%$. Another enniatin was also present in a smaller percentage. F. verticillioides 102 contained fusaric acid, trichosetin, beauverin and equisetin, where trichosetin had the highest peak with retention time $5.77 \mathrm{~min}$ and area percentage $15.3 \%$.

In our research isolate $F$. solani 149 showed the highest positive influence on cherry plant development. Chemical analysis showed that this isolate had a high production of integracide A and it is possible that integracide A acted as a plant growth enhancer. Singh et al (2003) discovered integracides from Fusarium sp. fermentation broths and determined its inhibitory activity against HIV-1 integrase, an important enzyme in the replication of HIV-1. Integracides belong to the family of tetracyclic triterpenoids, and integracide A, which is a sulfated ester, showed inhibitory activity against HIV-1 integrase.

Our research determined cyclosporine A in F. solani 112. None of the plants inoculated with it survived. It is possible that cyclosporine A had negative influence on plant development. Rodriguez et al. (2006) evaluated the antagonistic activity of nonpathogenic $F$. oxysporum against the pathogenic Sclerotinia sclerotiorum and identified active antifungal compounds. Cyclosporine A had negative influence on growth and sclerotia formation. According to them $F$. oxysporum could be used for fungal biological control of S. sclerotiorum and cyclosporine A is the main metabolite of its antagonistic activity in vitro.

Secondary metabolites isolated from $F$. verticillioides 102 were fusaric acid, trichosetin, beauverin and equisetin. Fusaric acid is a mycotoxin, has a role in plant pathogenesis and is toxic to animals. It also augments overall toxicity of other mycotoxins (Bacon et al., 1996) causing synergistic interactions. Bouizgarne et al. (2006) have discovered that nontoxic concentrations of fusaric acid can activate signal transduction compounds responsible for plant defense. According to them, secretion of low concentrations of fusaric acid by Fusarium genus causes different beneficial plant responses. Trichosetin was discovered by Marfori et al. (2002) as a product of dual culture of Catharanthus roseus and Trichoderma harzianum. It showed excellent antibacterial activity. Inokoshi et al. (2013) have determined that trichosetin, together with epi-trichosetin, produced by $F$. oxysporum, have antibacterial activity against Gram-positive bacteria. Trichosetin is an homolog of equisetin, also produced by $F$. verticillioides 102 . Equisetin is a mycotoxin, originally isolated from Fusarium equiseti, with antibiotic and cytotoxic activity which acts as an inhibitor of mitochondrial ATPases and HIV-1 integrase. Wheeler et al. (1999) have studied Fusarium pallidoroseum and $F$. equiseti (pathogenic to cotton) and discovered that both species contain equisetin. In their research, equisetin inhibited plant growth and caused necrotic lesions. Beauvericin was isolated for the first time from Beaveria bassiana and later was found in many other fungi. It is a mycotoxin with antimicrobial and cytotoxic activity (Wang and $\mathrm{Xu}, 2012$ ).

Enniatins, identified in F. subglutinans 111, are mycotoxins. Enniatins are metabolites with diverse biological activities, isolated mostly from Fusarium species, but also from Halosarpheia and Verticillium. They are contaminants of cereals (Fanelli et al., 2014), but at the same time have antifungal, antibiotic and cytotoxic activity. 29 enniatins have been isolated to date (Sy-Cordero et al., 2012), but only one, called fusafungine, is used for medical purposes. In general, mycotoxins have a role in plant disease pathogenesis and can be toxic to humans and animals (Van Burik and Magee, 2001).

To the best of our knowledge, none of the above mentioned secondary metabolites identified in the Fusarium species used in this study were previously mentioned as plant growth 
promoters therefore their true role in growth promotion needs to be further investigated. Another issue is that we are not familiar with the fungal production of secondary metabolites within a host. This means that we cannot be certain if the same secondary metabolites were produced by fungi after they were used for artificial infection. It is a fact that plant-host interaction is a complex system and fungal activities might be influenced by plant metabolites.

Wearn et al. (2012) investigated similarity between root and shoot endophytes in leaves and roots of Plantago lanceolata, Cirsium arvense and Rumex acetosa in winter and summer. Endophyte communities were more diverse in root tissues and in summer. Results showed very low similarity of endophyte communities within different host plant species and organs within an individual plant. The results show that many endophytes do not occur worldwide, but instead have plant and tissue specificity. This dissimilarity suggests a lack of systemic growth by the fungi from one tissue to another. According to the authors we should see individual plants as ecosystems of interacting microbes, determined by plant genetics, environmental conditions and interactions between the microbes.

In conclusion, our results show that endophytic Fusarium species isolated from symptomless weeds have significant influence on growth of cherry plants. Several secondary metabolites that were identified as major components of fungal extracts need to be investigated in order to determine their influence on plant growth promotion.

\section{References}

Aharwal RP, KumarS, Sandhu SS. 2016 - Endophytic mycoflora as a source of biotherapeutic compounds for disease treatment. Journal of Applied Pharmaceutical Science 6, 242-254.

Andrews M, Hodge S, Raven JA. 2010 - Positive plant microbial interactions. Annals of Applied Biology 157, 317-320.

Arnold AE. 2007 - Understanding the diversity of foliar endophytic fungi: progress, challenges, and frontiers. Fungal Biology Reviews 21, 51-66.

Bacon CW, Porter JK, Norred WP, Leslie JF. 1996 - Production of fusaric acid by Fusarium Species. Applied And Environmental Microbiology 62, 4039-043.

Bary A. de 1866 - Morphologie und Physiologie der Pilze, Flechten, und Myxomyceten. Hofmeister's Handbook of Physiological Botany, Volume II (Leipzig, Germany: Engelmann)

Bouizgarne B, El-Maarouf-Bouteau H, Madiona K, Biligui B, Monestiez M, Pennarun AM, Amiar Z, Rona JP, Ouhdouch Y, El Hadrami I, Bouteau F. 2006 - A putative role for fusaric acid in biocontrol of the parasitic angiosperm Orobanche ramosa. Molecular Plant-Microbe Interactions 19, 550-556.

Delaye L, García-Guzmán G, Heil M. 2013 - Endophytes versus biotrophic and necrotrophic pathogens - are fungal lifestyles evolutionarily stable traits? Fungal Diversity 60, 125-135.

Driver JA, Kuniyuki AH. 1984 - In vitro propagation of Paradox walnut rootstock. HortScience 19, 507-509.

Fanelli F, Ferracane R, Ritieni A, Logrieco AF, Mulè G. 2014 - Transcriptional regulation of enniatins production by Fusarium avenaceum. Journal of Applied Microbiology 116, 390399

Freeman EM. 1904 - The seed-fungus of Lolium temulentum L., the Darnel. Philosophical Transactions of the Royal Societies B 196, 1-27.

Gera Hol WH, de la Pena E, Moens M, Cook R. 2007 - Interaction between a fungal endophyte and root herbivores of Ammophila arenaria. Basic and Applied Ecology 8, 500-509.

Guerin P. 1898 - Sur la presence d'un champignon dans l'ivraie. Journal Botanique. 12, 230-238.

Gundel PE, Garibaldi LA, Wäli P R, Helander M, Dirihan S, Saikkonen K. 2014 - Fungal endophyte mediated occurrence of seminiferous and pseudoviviparous panicles in Festuca rubra. Fungal Diversity 66, 69-76. 
Hardoim PR, van Overbeek LS, Berg G, Pirttilä AM, Compant S, Campisano A, Döring, M, Sessitsch A. 2015 - The hidden world within plants: ecological and evolutionary considerations for defining functioning of microbial endophytes. Microbiology and Molecular Biology Reviews 79, 293-320.

Hardoim PR, van Overbeek LS, BerG, Pirttilä AM, Compant S, Campisano A, Doring M, Sessitsch A. 2015 - The hidden world within plants: ecological and evolutionary considerations for defining functioning of microbial endophytes. Microbiology and Molecular Biology Reviews 79, 293-320.

Heinig U, Scholz S, Jennewein S. 2013 - Getting to the bottom of Taxol biosynthesis by fungi. Fungal Diversity 60, 161-170.

Heslin MC, Douglas GC. 1986 - Effects of ectomycorrhizal fungi on growth and development of poplar plants derived from tissue culture. Scientia Horticulturae 30, 143-149.

Hyde KD, Soytong K. 2008 - The fungal endophyte dilemma. Fungal Diversity 33, 163-173.

Ilic J, Cosic J, Jurkovic D, Vrandecic K. 2012 - Pathogenicity of Fusarium spp. isolated from weeds and plant debris in eastern Croatia to wheat and maize. Agriculture 18, 7-11

Inokoshi J, Shigeta N, Fukuda T, Uchida R, Nonaka K, Masuma R, Tomoda H. 2013 - Epitrichosetin, a new undecaprenyl pyrophosphate synthase inhibitor, produced by Fusarium oxysporum FKI-4553. The Journal of Antibiotics 66, 549-54.

Keim J, Mishra B, Sharma R, Ploch S, Thines M. 2014 - Root-associated fungi of Arabidopsis thaliana and Microthlaspi perfoliatum. Fungal Diversity 66, 99-111.

Ludwig-Müller J. 2015 - Plants and endophytes: equal partners in secondary metabolite production?. Biotechnology Letters, 37(7), 1325-1334.

Marfori EC, Kajiyama S, Fukusaki E, Kobayashi A. 2002 - Trichosetin, a novel tetramic acid antibiotic produced in dual culture of Trichoderma harzianum and Catharanthus roseus Callus. Zeitschrift für Naturforschung 57, 465-70.

Machungo C, Losenge T, Kahangi E, Coyne D, Dubois T, Kimenju JW. 2009 - Effect of endophytic Fusarium oxysporum on growth of tissue-cultured banana plants. African Journal of Horticultural Science 2.

Murashige T, Skog F. 1962 - A revised medium for rapid growth and bioassays with tobacco tissue cultures. Physiologia Plantarum 15, 473-497.

Muria-Gonzalez MJ, Chooi YH, Breen S, Solomon PS. 2015 - The past, present and future of secondary metabolite research in the Dothideomycetes. Molecular Plant Pathology, 16, 92107.

Obledo EN, Barragan-Barragan LB, Gutierrez-Gonzalez P, Ramirez-Hernandez BC, Ramirez JJ, Benjamin Rodriguez-Garay B. 2003 - Increased photosyntethic efficiency generated by fungal symbiosis in Agave victoria- reginae. Plant Cell, Tissue and Organ Culture 74, 237241.

Pereira JO, Carneiro Vieira ML, Azevedo JL. 1999 - Endophytic fungi from Musa acuminata and their reintroduction into axenic plants. World Journal of Microbiology \& Biotechnology 15, $37-40$.

Petrini O. 1986 - Taxonomy of endophytic fungi of aerial plant tissues. In: Microbiology of Phyllosphere (eds.): N. Fokkema \& J. Van der Heuvel, Cambridge University Press, 175187.

Postic J, Cosic J, Jurkovic D, Vrandecic K, Saleh AA, Leslie JF. 2012 - Diversity of Fusarium species isolated from weeds and plant debris in Croatia. Journal of Phytopathology 160, 7681.

Promputtha I, Hyde KD, McKenzie EH, Peberdy JF, Lumyong S. 2010 - Can leaf degrading enzymes provide evidence that endophytic fungi becoming saprobes? Fungal Diversity 41, 89-99.

Redecker D, Kodner R, Graham LE. 2000 - Glomalean fungi from the Ordovician. Science 289, 1920-1921. 
Rodriguez MA, Cabrera G, Godeas A. 2006 - Cyclosporin A from a nonpathogenic Fusarium oxysporum suppressing Sclerotinia sclerotiorum. Journal of Applied Microbiology 100, 575-586.

Rolli E, Marasco R, Vigani G, Ettoumi B, Mapelli F, Deangelis ML, Pierotti CF, Borin S, Sorlini C, Zochi G, Daffonchio D. 2015 - Improved plant resistance to drought is promoted by the root-associated microbiome as a water stress-dependent trait. Environmental Microbiology $17,316-331$.

SAS/STAT. 1999 - User's guide, version 8. Cary: SAS Institute;

Schenk RU, Hildebrandt AC 1972 - Medium and techniques for induction and growth of monocotyledonous and dicotyledonous plant cell cultures. Canadian Journal of Botany 50, 199-204.

Singh SB, Zink DL, Dombrowski AW, Polishook JD, Ondeyka JG, Hirshfield J, Felock P, Hazuda DJ. 2003 - Integracides: tetracyclic triterpenoid inhibitors of HIV-1 integrase produced by Fusarium sp. Bioorganic \& Medical Chemistry 11, 1577-82.

Stierle A, Strobel GA, Stierle D. 1993 - Taxol and taxane production by Taxomyces andreanae, an endophytic fungus of Pacific yew. Science 260, 214-216.

Sy-Cordero AA, Pearce CJ, Oberlies NH. 2012 - Revisiting the enniatins: a review of their isolation, biosynthesis, structure determination and biological activities. The Journal of Antibiotics. 65, 541-549.

Van Burik, J, Magee PT. 2001 - Aspects of fungal pathogenesis in humans. Annual Reviews in Microbiology 55, 743-772.

Varma A, Verma S, Sudha Sahay N, Butehorn B, Franken P. 1999 - Piriformospora Indica, a cultivable plant-growth-promoting root endophyte. Applied and Environmental Microbiology 65, 2741-2744.

Varshney A, Dhawan V, Srivastava PS. 2000 - A protocol for in vitro propagation of lily through liquid stationary culture. In vitro Cellular and Developmental Biology Plant 36, 383-391

Wang Q, Lijian Xu L. 2012 - Beauvericin, a bioactive compound produced by fungi: A short review. Molecules 17, 2367-2377.

Wearn JS, Sutton BC, Morley NJ, Gange AC 2012 - Species and organ specificity of fungal endophytes in herbaceous grassland plants. Journal of Ecology 100, 1085-1092.

Wheeler MH, Stipanovic RD, Puckhaber LS. 1999 - Phytotoxicity of equisetin and epi-equisetin isolated from Fusarium equiseti and F. pallidoroseum. Mycological Research 103, 967973.

Zink D, Dufresne C, Liesch J, Martin J, 2005 - Identification/dereplication of natural products by LC-UV-MS Spectral search parameters. Poster presented at the Small Molecule Science Conference (COSMOS).

Zink D, Dufresne C, Liesch J, Martin J. 2002 - Automated LC-MS analysis of natural products: Extraction of UV, MS and retention time data for component identification and characterization. In Proceedings of the 50th ASMS Conference on Mass Spectrometry and Allied Topics. Orlando, Florida, June 2-6 2002. 